
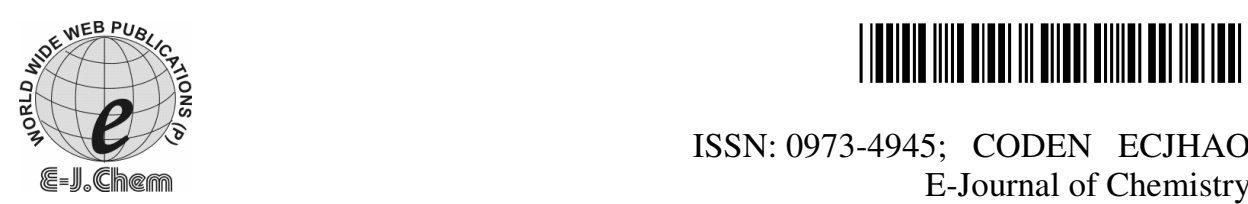

ISSN: 0973-4945; CODEN ECJHAO

E-Journal of Chemistry

http://www.e-journals.net 2009, 6(3), 633-638

\title{
Sorption and Preconcentration of Lead on Silica Nanoparticles Modified with Resacetophenone
}

\author{
ANUPREET KAUR* and USHA GUPTA \\ Department of Chemistry, Punjabi University, \\ Patiala, Punjab, India. \\ anupreetleo@yahoo.co.in
}

Received 19 September 2008; Accepted 1 November 2008

\begin{abstract}
The silica-resacetophenone ( $\mathrm{SiO}_{2}$ - $\left.\mathrm{RATP}\right)$ nanoparticles were used as a new sorbent for extraction of trace amounts of $\mathrm{Pb}$ (II) by batch technique. Conditions of the analysis such as preconcentration factor, effect of $\mathrm{pH}$, sample volume, shaking time, elution conditions and effects of interfering ions for the recovery of analyte were investigated. The adsorption capacity of nanometer $\mathrm{SiO}_{2}$-RATP was found to be $167.24 \mu \mathrm{mol} / \mathrm{g}$ at optimum $\mathrm{pH}$ and the detection limit $(3 \sigma)$ was 0.58 $\mu \mathrm{g} / \mathrm{L}$. The adsorption equilibrium of $\mathrm{Pb}$ (II) on nanometer $\mathrm{SiO}_{2}-\mathrm{RATP}$ was achieved in $20 \mathrm{~min}$. Adsorbed $\mathrm{Pb}$ (II) was easily eluted with $5 \mathrm{~mL}$ of $0.5 \mathrm{M}$ hydrochloric acid. The maximum preconcentration factor was 60 . The method was applied for the determination of trace amounts of $\mathrm{Pb}$ (II) in various natural water rivers.
\end{abstract}

Keywords: Chemically modified $\mathrm{SiO}_{2}$-nanoparticles, RATP, Preconcentration and Separation, Resacetophenone.

\section{Introduction}

Heavy metal ions contamination is recognized as a priority problem in environmental protection because these represent an environmental concern when present in uncontrolled and high concentration. Lead is considered as non-essential and highly toxic element with a series of cumulative effect. Its toxicity is comparable of any other metallic element. It is toxic to the human biosystem, and is among the common global pollutants arising from increasing industrialization. So, there is need to determine lead up to micro levels ${ }^{1-5}$. Despite the selectivity and sensitivity of analytical techniques, there is crucial need for the preconcentration of trace elements before their analysis due to their frequent low concentrations in numerous samples ${ }^{6-12}$. Nowadays, nanometer materials have become more important owing to its special physical and chemical propertities. Nanoparticles exhibit intrinsic surface activity due to high surface areas and can strongly chemisorb many chemical substances. The size, surface structure and interparticle interaction of nanomaterials determine 
their unique properties and the improved performances and make their potential application in many areas ${ }^{13-14}$. Nanoparticles such as $\mathrm{TiO}_{2}{ }^{15-16}, \mathrm{Al}_{2} \mathrm{O}_{3}{ }^{17}$ and $\mathrm{ZrO}_{2}{ }^{18-19}$ have been used for the preconcentration of many metal ions and give promising results when used for trace element analysis of different samples. In present work, chemically grafted $\mathrm{SiO}_{2}$-RATP nanoparticles have been used for the sorption and preconcentration of lead prior to their determination by spectrophotometric method. These chemically modified $\mathrm{SiO}_{2}$-RATP nanoparticles are characterized by Fourier Transform Infrared Spectroscopy (FT-IR).

\section{Experimental}

Absorbance of $\mathrm{Pb}(\mathrm{II})$ was measured with UV-Vis Shimadzu-1700 spectrophotometer. The $\mathrm{pH}$ values were controlled by century $\mathrm{Cp} 901$ digital $\mathrm{pH}$ meter.

\section{Reagents and standard solutions}

Unless otherwise stated, all reagents used were of analytical reagent grade and all solutions were prepared with double distilled water. The 3-aminopropyltriethoxysilane of GR grade was supplied by Acros Organics (USA). Resacetophenone (RATP) was obtained from Merck (Mumbai). Nanometer $\mathrm{SiO}_{2}$ and modified $\mathrm{SiO}_{2}$-RATP was synthesized according to the method reported ${ }^{20-21}$.

\section{Sample preparation}

Different water samples (River water) were analyzed without pretreatment. The $\mathrm{pH}$ was adjusted to 7.0 by using $0.2 \mathrm{M}$ disodium tetraborate/boric acid buffer prior to use.

\section{General procedure}

Aliquots of sample solutions containing the analytes of interest were prepared and $\mathrm{pH}$ value was adjusted to the selected value with disodium tetraborate/boric acid buffer $(0.2 \mathrm{M})$. Then, $20 \mathrm{mg}$ of $\mathrm{SiO}_{2}$-RATP nanoparticles were added, and the mixture was shaken vigorously for $20 \mathrm{~min}$ to facilitate sorption of metal ion onto the adsorbent. $\mathrm{Pb}(\mathrm{II})$ sorbed on the sorbent was eluted with $5 \mathrm{~mL}$ of $0.5 \mathrm{M}$ hydrochloric acid to get free metal ions, the solution was neutralized with $2 \mathrm{M}$ sodium hydroxide and were determined by standard spectrophotometric method.

\section{Results and Discussion}

\section{FT-IR spectrum analysis}

The chemical grafting of resacetophenone the surface of nanometer $\mathrm{SiO}_{2}$ was confirmed by FT-IR spectrum. FT-IR spectra of resacetophenone, nanometer-SiO 2 , nanometer $-\mathrm{SiO}_{2}$ RATP, respectively (Figure 1). It reveals that main absorption peaks of nanometer $\mathrm{SiO}_{2}$ $\left(3448.0,1642.5,1404,1070.2,964.2,798.8 \mathrm{~cm}^{-1}\right)$ are in agreement with standard spectrum ${ }^{17}$ of $\mathrm{SiO}_{2}$. The FT-IR spectrum of nanometer $-\mathrm{SiO}_{2}-\mathrm{RATP}$, exhibits a band at $1613.9 \mathrm{~cm}^{-1}$ which appears to be contributed to by $\mathrm{C}=\mathrm{N}$ stretching. The phenyl vibrations appears at $1493.9 \mathrm{~cm}^{-1}$ and $1373 \mathrm{~cm}^{-1}$. The above experimental results suggest that nanometer $\mathrm{SiO}_{2}$ has been successfully modified by resacetophenone.

\section{Effect of $\mathrm{pH}$ on enrichment recovery}

The adsorption of $\mathrm{Pb}$ (II) on nanometer $\mathrm{SiO}_{2}$-RATP was studied at different $\mathrm{pH}$ value (3.4 10.0) following the recommended procedure. The results of effect of $\mathrm{pH}$ on the recoveries of the metal ions are given in (Figure 2). A quantitative recovery ( $\geq 95 \%)$ was found for $\mathrm{Pb}(\mathrm{II})$ in the $\mathrm{pH}$ range of 7.0-10.0. 


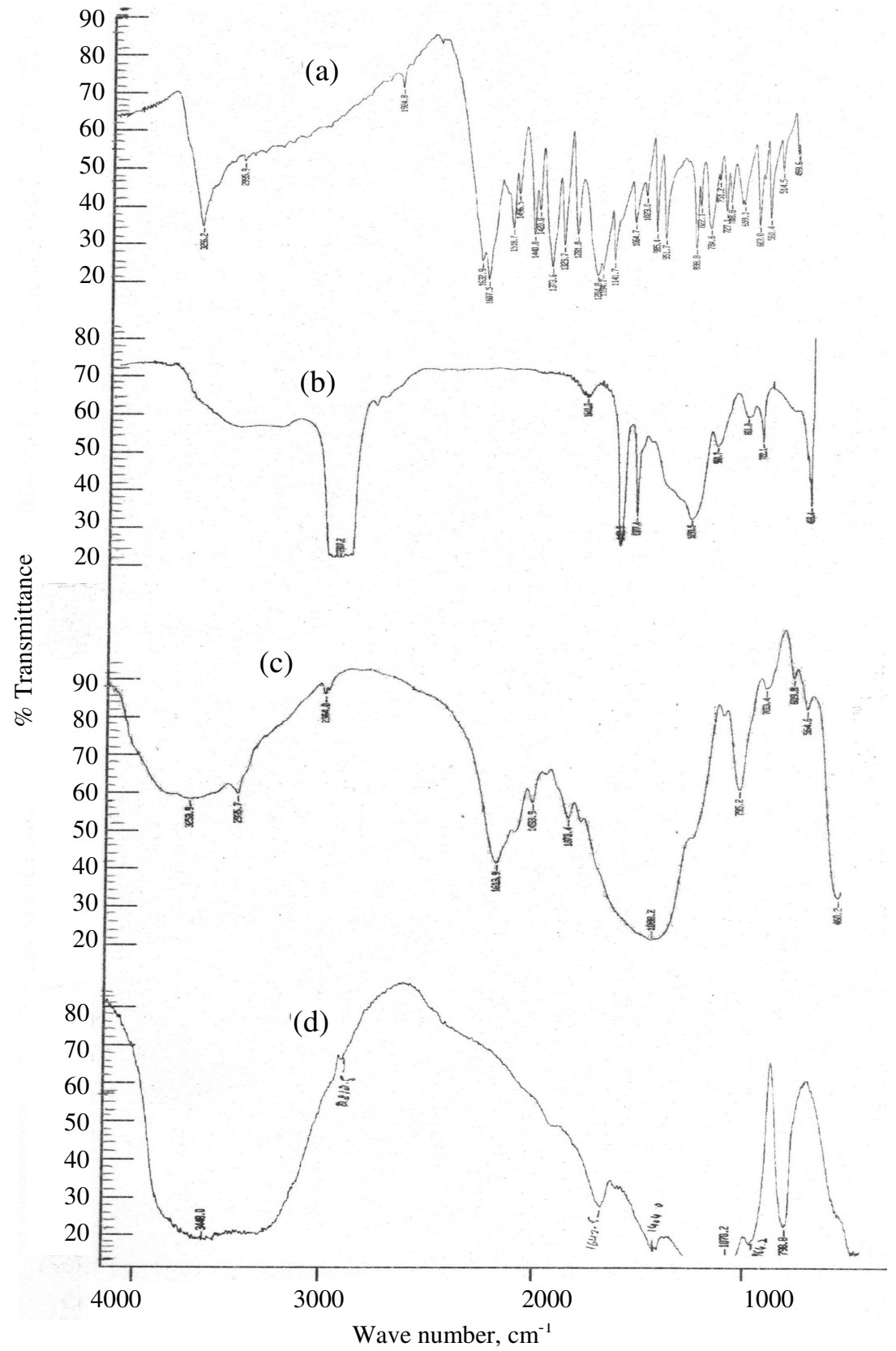

Figure 1. FTIR spectra (a) Resacetophenone (b) Nanometer $\mathrm{SiO}_{2}$ - Resacetophenone (c) Nanometer $\mathrm{SiO}_{2}-$ APTES (d) Nanometer $\mathrm{SiO}_{2}$. 


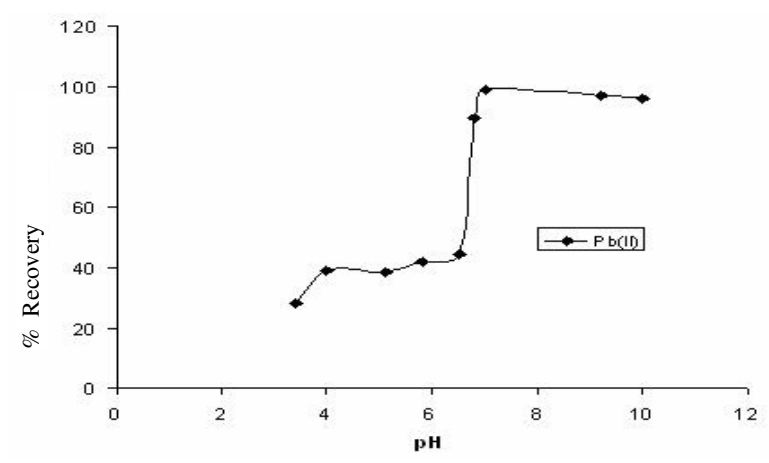

Figure 2. Effect of $\mathrm{pH}$ on analyte recovery.

\section{Effect of eluent concentration and volume}

Elution of $\mathrm{Pb}(\mathrm{II})$ from nanometer $\mathrm{SiO}_{2}$-RATP sorbent was investigated by using different concentrations of hydrochloric acid and found quantitative recoveries $(\geq 95 \%)$ of $\mathrm{Pb}$ (II) could be obtained using $5 \mathrm{~mL}$ of $0.5 \mathrm{M}$ hydrochloric acid as eluent. The results of effect of eluent concentration and volume are given in Table 1 and Table 2.

Table 1. Effect of concentration of $\mathrm{HCl}$ solution on elution of $\mathrm{Pb}(\mathrm{II})(\mathrm{n}=3)$.

\begin{tabular}{ccccccc}
\hline $\begin{array}{c}\text { Concentration of eluent } \\
\mathrm{M}\end{array}$ & 0.2 & 0.5 & 1.0 & 2.0 & 4.0 & 6.0 \\
\hline Recovery, \% & 57.76 & 99.46 & 72.68 & 43.61 & 33.28 & 22.18 \\
\hline
\end{tabular}

Table 2. Effect of volume of $\mathrm{HCl}$ solution on elution of $\mathrm{Pb}(\mathrm{II})(\mathrm{n}=3)$.

\begin{tabular}{ccccccc}
\hline Volume of eluent, $\mathrm{mL}$ & 2.0 & 4.0 & 5.0 & 6.0 & 7.0 & 10.0 \\
\hline Recovery, \% & 45.90 & 64.26 & 99.08 & 95.25 & 76.51 & 57.38 \\
\hline
\end{tabular}

\section{Effect of nanometer $\mathrm{SiO}_{2}$-RATP amount}

To optimize the amount of sorbent on quantitative retention of analyte, different amounts (10-60 $\mathrm{mg}$ ) of $\mathrm{SiO}_{2}$-RATP nanoparticles were added into the solution following and the experiment was performed. Quantitative extraction of the $\mathrm{Pb}(\mathrm{II}) \geq 95 \%$ was obtained in the range of $20-35 \mathrm{mg}$ of nanometer $\mathrm{SiO}_{2}$-RATP. $20 \mathrm{mg}$ of sorbent was found to be sufficient for further studies.

\section{Effect of shaking time}

The sorption of $\mathrm{Pb}(\mathrm{II})$ on $20 \mathrm{mg}$ of RATP modified silica nanoparticles were studied for different shaking time $(5-30 \mathrm{~min})$. The results indicated that within $20 \mathrm{~min}$ the quantitative extraction of $\mathrm{Pb}(\mathrm{II})$ was $\geq 95 \%$.

\section{Adsorption capacity $\left(Q_{S}\right)$}

The adsorption capacity ${ }^{22}$ is an important factor as it determines how much sorbent is quantitatively required to concentrate the analytes from a given solution. A breakthrough curve was obtained by plotting the concentration (mg/L) vs. the $\mu \mathrm{mol}$ of $\mathrm{Pb}$ (II) sorbed per gram. From the breakthrough curve the amount of $\mathrm{SiO}_{2}$ - $\mathrm{RATP}$ nanoparticles for $\mathrm{Pb}$ (II) was found to be $167.24 \mu \mathrm{mol} / \mathrm{g}$ at $\mathrm{pH} 7.0$ respectively. The results are given in Figure 3 .

\section{Effect of sample volume}

In order to explore the possibility of concentrating low concentration of analytes from large volumes, the effect of sample volume on the retention of $\mathrm{Pb}$ (II) was also investigated. 
For this purpose $50,100,150,200,250,300,350,400,450$ and $500 \mathrm{~mL}$ of the sample solutions containing $1.0 \mu \mathrm{g} \mathrm{Pb}$ (II) was shaken, quantitative recoveries $(\geq 95 \%)$ were obtained for sample volume of $\leq 300 \mathrm{~mL}$ for $\mathrm{Pb}(\mathrm{II})$. The results are given in Figure 4 .

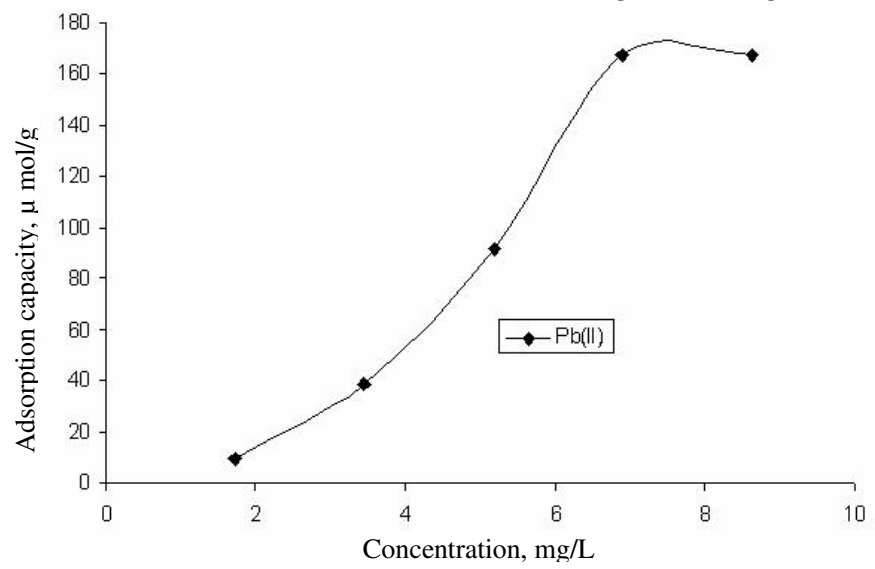

Figure 3. Adsorption capacity of $\mathrm{Pb}(\mathrm{II})$ on nanometer $\mathrm{SiO}_{2}-\mathrm{RATP}$.

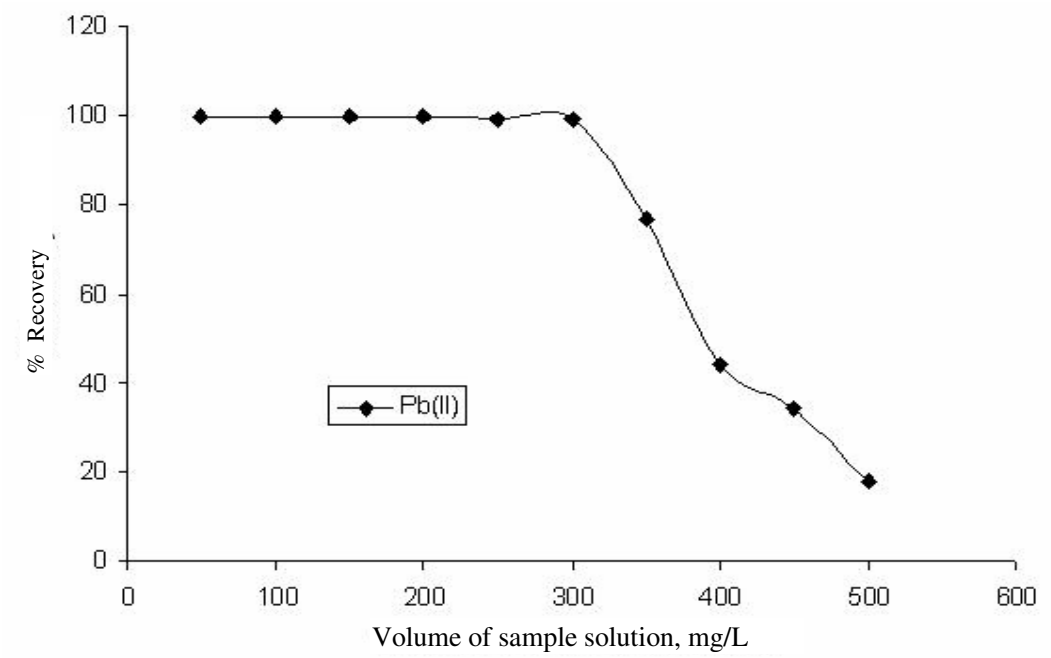

Figure 4. Effect of sample volume on analyte recovery.

Effect of coexisting ions

The effect of common coexisting ions on the sorption of $\mathrm{Pb}(\mathrm{II})$ was investigated. In these experiments, a solution of $2.0 \mu \mathrm{g} / \mathrm{mL}$ of $\mathrm{Pb}$ (II) that contains the added interfering ion was analyzed according to the recommended procedure. The tolerance limit $(\mathrm{mg} / \mathrm{L})$ for anions such $\mathrm{Cl}^{-}, \mathrm{Br}^{-}, \mathrm{SO}_{4}{ }^{2-}, \mathrm{PO}_{4}{ }^{3-} \mathrm{NO}_{3}{ }^{-}$, and EDTA The tolerance limits of these anions in $\mathrm{mg} / \mathrm{mL}$ were $0.003,0.02,0.07,0.005,0.05$, and 0.02 respectively. The tolerance limits in $\mathrm{mg} / \mathrm{mL}$ for $\mathrm{Ca}(\mathrm{II}), \mathrm{Mg}(\mathrm{II}), \mathrm{Cu}(\mathrm{II}), \mathrm{Co}(\mathrm{II}), \mathrm{Ni}(\mathrm{II}), \mathrm{Cr}(\mathrm{III}), \mathrm{Mn}$ (II), $\mathrm{Zn}$ (II) and $\mathrm{Cd}(\mathrm{II})$ were $0.05,0.10,0.09$, $0.010,0.010,0.010,0.08,0.075,0.011$ and 0.07 respectively.

\section{Analytical precision and detection limit}

Under the selected conditions, three portions of $\mathrm{Pb}(\mathrm{II})$ standard solutions was enriched and analyzed simultaneously following the experimental method. The relative standard deviation 
(RSD) of the method was $3.8 \%$ for the determination of $5.0 \mu \mathrm{g} \mathrm{Pb}$ (II) in $100 \mathrm{~mL}$ river water samples. The detection limit of this method for $\mathrm{Pb}(\mathrm{II})$ was $0.58 \mu \mathrm{g} / \mathrm{L}$.

\section{Applications}

The developed method has been applied for the determination of trace $\mathrm{Pb}(\mathrm{II})$ in river water. For analysis, $200 \mathrm{~mL}$ of sample was extracted following the method described above. The results are given in the Table 3 .

Table 3. Analytical recovery of $\mathrm{Pb}(\mathrm{II})$ added to natural water samples.

\begin{tabular}{cccc}
\hline Samples & Added, $\mu \mathrm{g} / \mathrm{L}$ & Found, $\mu \mathrm{g} / \mathrm{L}$ & Recovery, \% \\
\hline Ganga river & 0.0 & 19.28 & --- \\
(Delhi) & 5.0 & 23.88 & 97.95 \\
& 10.0 & 28.93 & 98.23 \\
Yammuna river & 0.0 & 17.45 & --- \\
(Delhi) & 5.0 & 20.96 & 98.42 \\
& 10.0 & 27.62 & 96.39 \\
\hline
\end{tabular}

\section{Conclusion}

Resacetophenone anchored silica nanoparticles were prepared and used as solid sorbent for preconcentration and separation of trace $\mathrm{Pb}$ (II) prior to their determination. These analytes can be easily screened at $\mu \mathrm{g} / \mathrm{mL}$ level with preconcentration times of $20 \mathrm{~min}$ and preconcentration factor of 60 for $\mathrm{Pb}$ (II).The method can be used as screening to estimate the total concentration of $\mathrm{Pb}$ (II) present in a large number of samples and thus avoiding the continuous use of expensive instrumentation in routine analysis. The results of determination have been found to be accurate and reproducible.

\section{References}

1. Camel V, Spectrochim Acta, 2003, 58, 1177.

2. Izatt R M, Bradshow J S and Bruening R L, Pure Appl Chem., 1996, 68, 1237.

3. Mohammadosseini M and Tehrani M.S, J Chin Chem Soc., 2006, 53, 1119.

4. Kiptoo J K, Nagila J L and Silavwe N D, Microchim Acta, 2008, 160, 211.

5. Fang G, Liu Y, Meng S and Guo Y, Talanta, 2002, 57, 1155.

6. Liska J, J Chromatogr A, 1993, 655, 163.

7. Martinez D, Cugat M J, Borrull F and Callul M, J Chromatogr A, 2000, 65, 902.

8. Bruzzoniti M C, Sarzanini C and Mentassi E J, J Chromatogr A, 2000, 902, 289.

9. Cao G H and Fang Z L, Fresenius J Anal Chem., 1998, 360, 156.

10. Yang D, Cheng X J, Liu Y W and Wiang S, Microchim Acta, 2004, 147, 219.

11. Alonso E V, De Torres A G and Pavon J M C, Talanta, 2001, 55, 219.

12. Henglein A, Chem Rev., 1989, 89, 1861.

13. Xue Q J and Xu K, Prog Chem., 2000, 12, 431.

14. Okuyama K and Lenggoro I W, Chem Eng Sci., 2003, 58, 5377.

15. Vassileva E and Furuta N, Fresenius J Anal Chem., 2001, 370, 52.

16. Hosono E, Fujihara S, Kimura T and Imai H, J Sol-Gel Sci Technol., 2004, 29, 71.

17. Hiraide M, Wasawa J I and Kawaguchi H, Talanta, 1997, 44, 231.

18 Sarkar S, Cara PW, Mcneff C V and Subramanian A., J Chromatogr B, 2003, 790, 143.

19. Ragai J and Selim S T, J Colloid Interface Sci., 1987, 115, 139.

20. Stober W, Fink A and Bohn E, J Colloid Interface Sci., 1968, 26, 62.

21. Toral, M I, Lara N, Narvaez J and Richter P, J Chilean Chemical Society, 2004, 49, 163.

22. Maquieira A, Elmahadi H and Puchades R, Anal Chem., 1994, 66, 3632. 


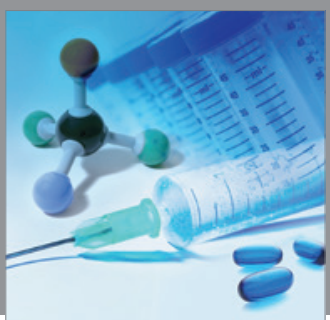

International Journal of

Medicinal Chemistry

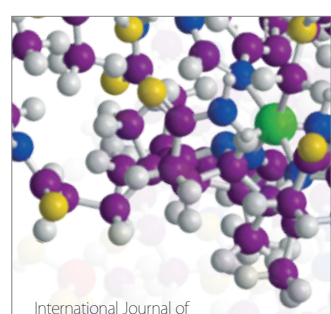

Carbohydrate Chemistry

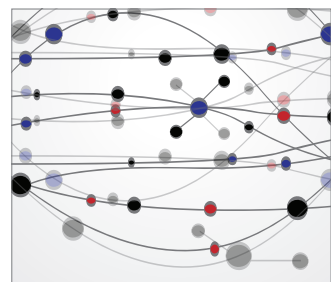

The Scientific World Journal
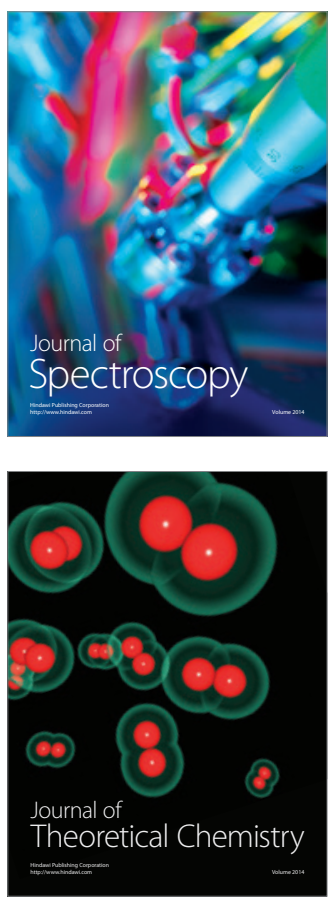
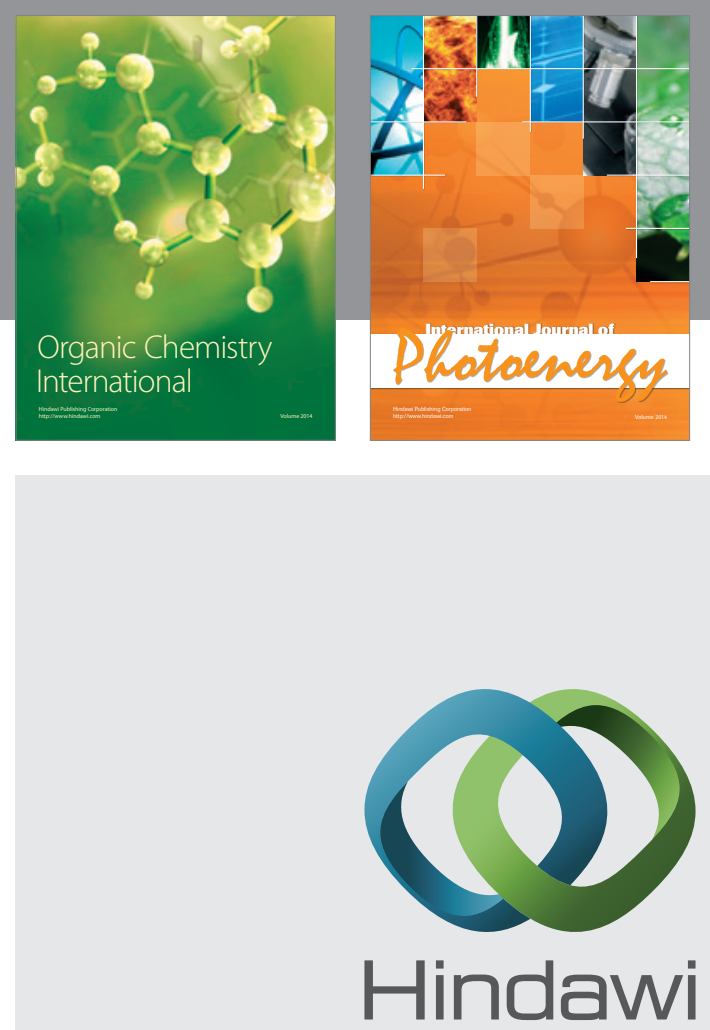

Submit your manuscripts at

http://www.hindawi.com
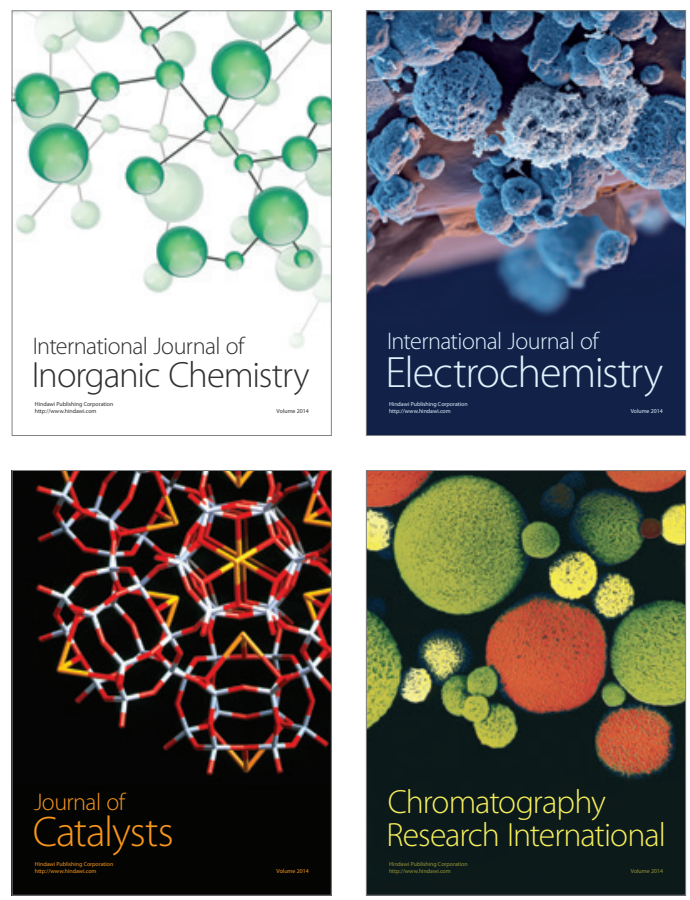
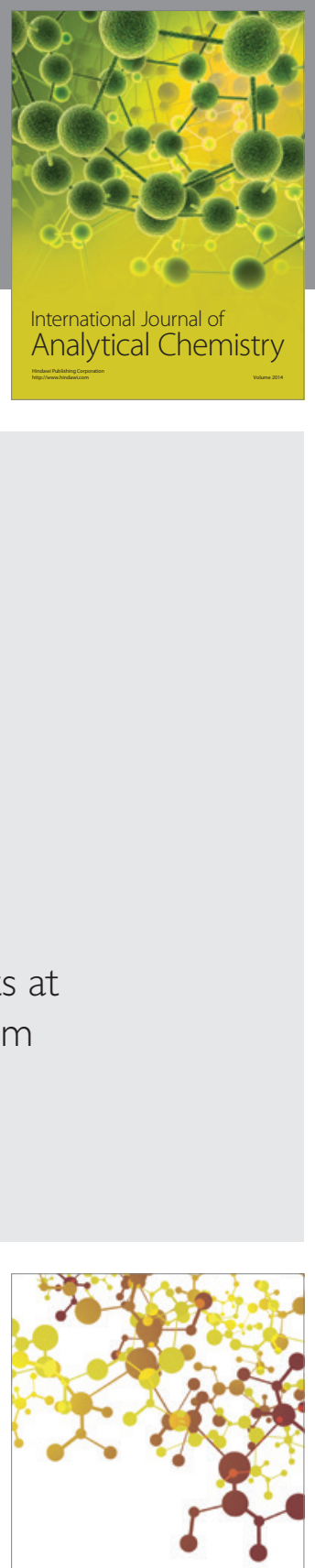

Journal of

Applied Chemistry
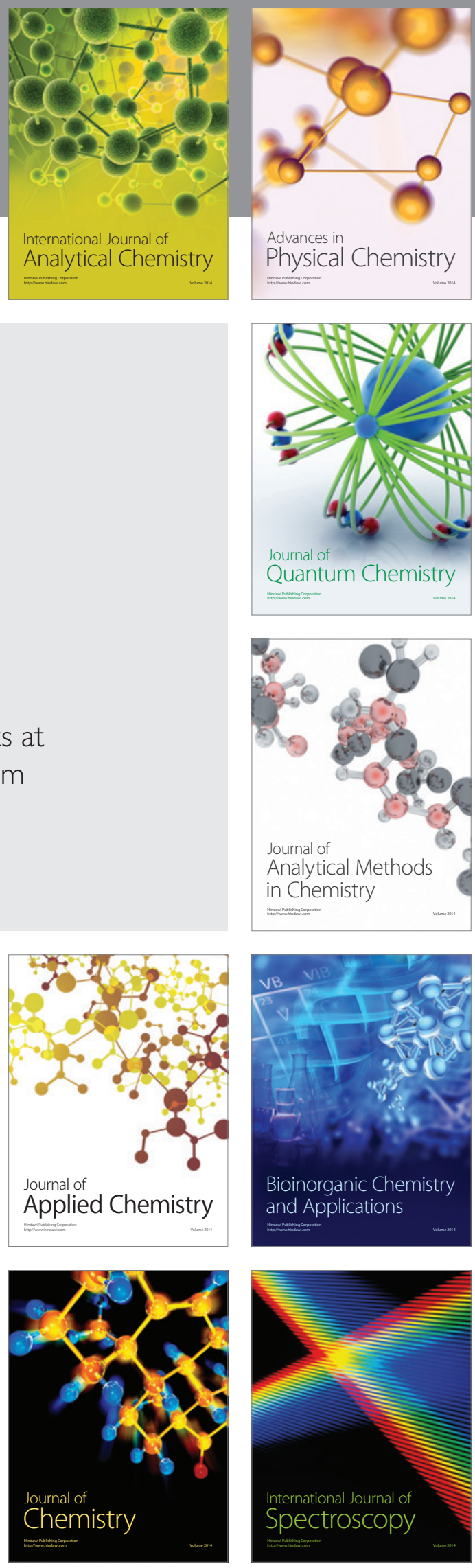